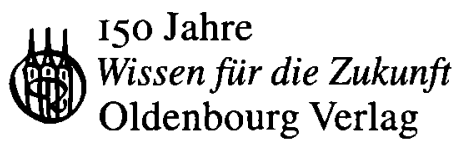





\title{
Wie Chinesen denken
}

Denkphilosophie, Welt- und Menschenbilder in China

\author{
von \\ Ning Huang
}

Oldenbourg Verlag München 
Bibliografische Information der Deutschen Nationalbibliothek

Die Deutsche Nationalbibliothek verzeichnet diese Publikation in der Deutschen Nationalbibliografie; detaillierte bibliografische Daten sind im Internet über $<$ http://dnb.d-nb.de> abrufbar.

\author{
(C) 2008 Oldenbourg Wissenschaftsverlag GmbH \\ Rosenheimer Straße 145, D-81671 München \\ Telefon: (089) 45051-0 \\ oldenbourg.de
}

Das Werk einschließlich aller Abbildungen ist urheberrechtlich geschützt. Jede Verwertung außerhalb der Grenzen des Urheberrechtsgesetzes ist ohne Zustimmung des Verlages unzulässig und strafbar. Das gilt insbesondere für Vervielfältigungen, Übersetzungen, Mikroverfilmungen und die Einspeicherung und Bearbeitung in elektronischen Systemen.

Lektorat: Wirtschafts- und Sozialwissenschaften, wiso@oldenbourg.de

Herstellung: Anna Grosser

Coverentwurf: Kochan \& Partner, München

Gedruckt auf säure- und chlorfreiem Papier

Gesamtherstellung: MB Verlagsdruck, Schrobenhausen

ISBN 978-3-486-58814-9 